\title{
Resisting Devolution? The Advisory Roles of Political Scientists in Belgium
}

\author{
Marleen Brans, David Aubin, and Ellen Fobé
}

\subsection{INTRODUCTION}

The Belgian policy advisory system (PAS) is traditionally characterized by federalism, neo-corporatist consociationalism, and a hegemony of political parties referred to as partitocracy (Vandeleene et al., 2019). This chapter first describes these features and their implications for the production and use of policy advice by political scientists. It also considers the impact of observed trends of pluralization, professionalization, and politicization on the policy advisory system, as well as the outcome of a more recent move in the PAS towards evidence-free policy-making (Brans \& Blum, 2020). The chapter then examines the position and operation of policy advisors, including political scientists, within the Belgian advisory system's arenas. The third section analyses the types of advice provided by political

\footnotetext{
M. Brans $(\bowtie) \bullet$ E. Fobé

Public Governance Institute, KU Leuven, Leuven, Belgium e-mail: marleen.brans@kuleuven.be; ellen.fobe@kuleuven.be

D. Aubin
}

UCLouvain, Ottignies-Louvain-la-Neuve, Belgium e-mail: david.aubin@uclouvain.be

(C) The Author(s) 2022

M. Brans, A. Timmermans (eds.), The Advisory Roles of Political

Scientists in Europe, https://doi.org/10.1007/978-3-030-86005-9_5 
scientists. The fourth section then presents the survey data and considers whether the policy advisory activities of political scientists in Francophone and Dutch-speaking universities have followed, or resisted the bipolar, centrifugal devolution that characterizes the Belgian federal state. Are advisory activities consistent with what would be expected from a devolved policy advisory system on both sides of the language border? One of the most salient cases of policy advice offered by political scientists in Belgium, was meant to reinforce a federal space in the face of bipolar devolution, by advocating the creation of a federal electoral district. The last section of this chapter presents and discusses this particular case. The concluding section revisits the features of the Belgian policy advisory system and the position of political scientists within it.

\subsection{Features of the Belgian Policy Advisory System: Tradition and Trends}

Three features of the Belgian political system condition the configuration of advisory actors and the possible space and roles taken by political scientists. The system is characterized by federalism, consensualism, and partitocracy (Vandeleene et al., 2019). What do these features mean for the advisory roles of political scientists? Furthermore, are there any notable trends that run counter to the traditional legacies of the Belgian policy advisory system? The pluralization and professionalization of policy advice need to be considered, as does the simultaneous move towards its politicization.

\subsubsection{Federalism}

Belgian federalism today is the outcome of a long process of state reform. The federated entities are not only territorial regions, but also linguistic communities: the Flemish Region, the Walloon Region, the Frenchspeaking community, the German speaking community, the Bilingual Region of Brussels-Capital. Belgium has a total of nine parliaments and governments. Moreover, there is no hierarchy of norms among the federal laws and decrees of the nation's communities and regions. Needless to say, Belgian federalism is particularly complex, and political scientists are often called on to help explain these complex features to a broader audience. 
Following the reform of the Belgian State, Belgium's bilingual universities no longer exist, and higher education in Flanders and in Francophone Belgium are each governed by a corresponding minister and ministry. "This has led to a clear division in political science as a discipline, with two political science organizations, separate curricula, recruitment procedures, and different adaptation patterns to the Bologna reforms" (De Winter et al., 2007, p. 57). As an example of the latter, the Bologna Process led to the establishment of master's degree programmes of differing durations, namely two years in Francophone Belgium and one year in Flanders.

Belgian federalism has parcelled up the advisory system as well as public debate. For example, few political scientists will speak to both the Francophone and Flemish media. Nor are there many applied research consortia operating across the language border, particularly after the devolution of science policy to the federated entities.

\subsubsection{Consensualism}

A second characteristic of Belgium is its consociationalist tradition (Lijphart, 2012; Swenden et al., 2006), which permeats both community levels and societal pillars. Consociationalism organizes, through elections with proportional representation, a distribution of power along three societal cleavages: linguistic, religious, and class-based (Mabille, 1997). The catholic, liberal, and socialist pillars provide public services to the population (social security, education, health, sports and youth services) in alignment with their corresponding political parties. Moreover, the universities in Belgium are also split along denominational lines: freethinking universities, Catholic universities, and State universities. Even though Belgium has undergone a process of de-pillarization, and the link between society and political parties has weakened, the pillars are still present, are powerful, and contribute towards political stability (Fraussen \& Beyers, 2016). One consequence of the consensual policy advisory style associated with pillarized politics is the representative sampling of experts across linguistic, partisan and denominational lines. This is the case in applied research consortia for example, which include universities from different denominations. Also in expert hearings of Parliament, the selection of speakers representing different ideologies and languages is evident (Van Gasse, 2018).

Belgian pillarization has been termed a moderate neo-corporatism (Fraussen \& Beyers, 2016). This form of neo-corporatism goes hand-inhand with the dominant position of representative interest groups in a 
strongly institutionalised system of advisory bodies (Fobé et al., 2013). The majority of these advisory bodies prioritize lay representative expertise over independent academic advice (Van Damme et al., 2011). Political scientists rarely feature in formal advisory bodies in Belgium. Nor are advisory bodies the prime recipients of political scientists' advice. It appears that political scientists prefer advising civil society actors directly rather then providing advice to the advisory bodies representing these actors. As will be shown, civil society actors are the second most important recipients of policy advice from political scientists in Belgium.

\subsubsection{Partitocracy}

The nature of the proportional election system contributes to the partitocratic features of the political system (De Winter \& Dumont, 2006). Maintaining large coalition governments requires considerable party discipline in parliament, and strong ministerial offices staffed with ministerial advisors acting as powerful gatekeepers of the advice taken up in the decision-making process (Brans et al., 2017a). Toughly-negotiated coalition agreements represent further sturdy gates; they consist of voluminous contracts between coalition partners, determining what is addressed by the political agenda and what will be kept off the agenda.

Partitocracy is carried over from parliamentary and executive politics to a politicized administration (Brans et al., 2022, forthcoming). Academics too are often implicitly labelled on the basis of their political orientation. This arguably determines the selection or censuring of academics in parliamentary committee hearings or the media. However, there is no conclusive empirical evidence of the political inclination of political scientists in Belgium. In the public's mind, political scientists are generally perceived as being on the left side of the political spectrum, although there are certainly also examples of right-wing political scientists operating as opinion makers. Overall, as a 2019 survey by the quality newspaper De Standaard (2019) shows, humanities scholars (including political scientists) tend to be more left-leaning than their colleagues in the pure sciences. Research across Europe confirms this finding (van de Werfhorst, 2020).

\subsubsection{Trends}

Since the 2000s, the Belgian policy advisory system has witnessed greater pluralization, professionalization and politicization (Pattyn et al., 2019). 
As in other countries, the Belgian policy advisory system has become more competitive than it was in the past. The pluralization of advice has expanded the numbers and types of advisor, including emergent actors such as think tanks and consultancy companies. At the same time, the policy advisory system has become more professionalized, and the Belgian political science community has produced more advice via institutionalised applied research programmes. Belgian political scientists have also set up more effective outreach mechanisms, for example through the establishment of professional evaluation societies. There is also anecdotal evidence, albeit no strong research findings, pointing to the fact that the Belgian advisory system is marked by politicization. Pluralized expert-based advice in Belgium does not sit well with recent moves towards majoritarian politics, or with the continued reliance on ministerial cabinets (Pattyn et al., 2019).

Recently, scholars have noted a move towards "policy-based evidencemaking" (Straßheim \& Kettunen, 2014), and even towards "evidencefreed policy-making" (Brans \& Blum, 2020). Furthermore, in Belgium these developments appear to have had an impact on the policy advisory system and on the role of political scientists as policy advisors. For instance, long-term fundamental research projects conducted by policy research centres have been replaced by short-term, applied research assignments. On top of that, substantial budget cuts have limited the opportunities for structurally and publically-funded research in Belgium. Of note, also, is the uptake of behavioural insights in policy-making, which addresses rather narrow, unambitious policy implementation issues (Raymaekers \& Brans, 2020). The enthusiasm over the evidence-based policy-making movement seen in the first decade of the new millennium, has recently waned. There have even been cases in the broader domain of the social sciences where expert evidence is deliberately ignored, and where the producers thereof are discredited or denied access. ${ }^{1}$

\footnotetext{
${ }^{1}$ They are close to socialists and Marxists, activists rather than academics, the Belgian State Secretary of Poverty Alleviation said about the experts who tabled a report on poverty ( $D e$ Standaard, 2017).
} 


\subsection{The Belgian Policy Advisory System: Location and Configuration}

\subsubsection{Government Arena}

There are many political scientists working in the government arena, as federal and devolved bureaucracies are the prime destinations for political science graduates (Ilonszki \& Roux, 2021). From a 2015 study on policy analytical work, it transpired that about one-fifth of the surveyed civil servants in the federal, Flemish and francophone administrations held a degree in Political and Social Sciences (Aubin et al., 2017; Fobé, 2020).

What about political science academics? Do they obtain positions in government during the course of their academic careers? The answer is that political science academics have rarely held political or legislative office (one exception being Paul Magnette, who was appointed president of the francophone socialist party). However, there is a certain tradition of academics taking leave to serve as extensions of ministers in advisory or leadership positions in ministerial cabinets. Those from academia who engage directly in politics are more often than not law scholars, with the occasional economist or substantive policy analyst operating in the field of migration or education. ${ }^{2}$

Political scientists are, however, regularly invited to parliamentary committee meetings and have occasionally also chaired parliamentary hearings such as the 2000 hearing investigating the Belgian State's responsibility for the murder of the first democratically-elected Congolese prime minister, Patrice Lumumba. Very occasionally, political scientists have also left university altogether to take up senior posts in international agencies, as with Hans Bruyninckx who was appointed head of the European Environment Agency.

\footnotetext{
${ }^{2}$ As for law scholars, see for instance Rik Torfs, Boudewijn Bouckaert and Francis Delpérée as MPs, Koen Geens as Minister of Justice, André Alen as chief of cabinet of the late PM Jean Luc Dehaene, Johan Vandelanotte as chief of cabinet at the Ministry of the Interior and as Minister and Vice Prime Minister. Notable economists have been Gaston and Mark Eyskens, both former Prime Ministers; Paul De Grauwe as MP, Frank Vandenbroucke as Minister, and François-Xavier de Donnéa as minister and mayor of Brussels.
} 


\subsubsection{Societal Arena}

Civil society is traditionally strong in Belgium, with an enduring legacy of domination by strong representative umbrella organizations. Political scientists have been known to take up leadership positions in such umbrella NGOs, like the Environmental Union for a Better Environment, or Beweging.Net, the former Christian Democratic Workers Union. ${ }^{3}$

Political scientists in Belgium tend to be rather active in the media. They have prominent columns in newspapers, are guests on current affair talk shows or radio broadcasts. They also appear on television election programmes.

\subsubsection{Intersections Between Arenas: Political Scientists} in Think Tanks, Advisory Bodies and Applied Research Institutes

Think tanks lie at the intersection of the academic and societal arenas. They have only started to emerge quite recently in Belgium, as their function is traditionally "performed by professionalized political party study centres" (Pattyn et al., 2017). Even though there is no strong think-tank culture, several political scientists are connected to, or are on the boards of, think tanks, or they provide input to the occasional papers these centres of policy advice produce. The left-wing Minerva is a case in point.

Advisory bodies and applied research centres operate at the intersection between academia and the government arena. There are no precise figures for the total number of commissions and committees providing policy advice to policy-makers across the different levels of government in Belgium. It is clear, however, that the number of advisory bodies is relatively high in comparison to neighbouring countries Germany, France and the Netherlands, with different counts ranging from 250 to 600, depending on the definition of the term (Fobé et al., 2017). Yet, the composition of advisory bodies in Belgium is generally representative and lay, as opposed to independent and academic-expert based, thus placing these bodies at the intersection of the government and societal arenas. This means that most permanent advisory bodies will only occasionally feature an academic in the midst of interest organization representatives, if at all. One notable exception is the short-lived experience of the Flemish

\footnotetext{
${ }^{3}$ Hans Bruyninckx in Bond Beter Leefmilieu, before becoming Head of the European Environment Agency.
} 
advisory body on governmental affairs (Fobé et al., 2013). In the mid2000s, when the Flemish government reviewed its strategic advisory system, and amended the rules governing the composition of advisory boards, only one of those boards was allowed any significant presence of political scientists/public administration experts. The nomination of four members, including the chair, was neatly in keeping with the Flemish university landscape, with one scholar appointed from each of the four main universities. After 8 years, however, the board was abolished, officially for reasons of efficiency, but in practice also because it competed with other advisory structures at the intersection of government and academia (applied research centres), and of government and the societal arena (other advisory bodies such as the Socio-Economic Council of Flanders).

As to applied research centres, Flanders invested heavily in such structural interfaces between policy-makers and academics in many different policy domains. In a consortium of public administration and public policy scholars from different Flemish universities, academia was contracted for a period of 20 years, comprising four consecutive generations of funding. Scholars carried out both long-term and short-term applied research, with a view to advising the Flemish government on a wide range of administrative reform issues, such as evaluating the new advisory structure, the management capacity of local government, and the timely transposition of European legislation. At the Belgian federal level too, multi-university consortia conduct applied research, although the policy-science interface at that level remains fairly fragmented (Brans et al., 2017b; Pattyn et al., 2019).

\subsection{Roles And Advisory Activities of Political Scientists}

Turning to the survey evidence, we first examine what kind of content political scientists circulate within arenas and at the arenas' intersections in the policy advisory system. Given the characteristics of the Belgian policy advisory system and the wide range of recipients in the crowded policy advisory space, we would expect political scientists to express a broad range of knowledge statements. The survey data also informs us about the ideal conceptions that political scientists have of their own advisory roles, and about the media they use within the framework of engagement with policy-makers. 
What we find is that there are hardly any public intellectuals, and very few pure academics, among Belgium's academic political scientists. The largest group turns out to be those who actively target a broad range of actors, with a variegated repertoire of advice including normative statements. These findings are discussed in more detail below.

\subsubsection{Highly-Active Scholars}

The survey results comprise the advisory activities of 87 Belgian respondents. We find that these Belgian political scientists are more active as policy advisors than the average political scientist in Europe. More than half of those responding to the survey state that they regularly provide some form of advice.

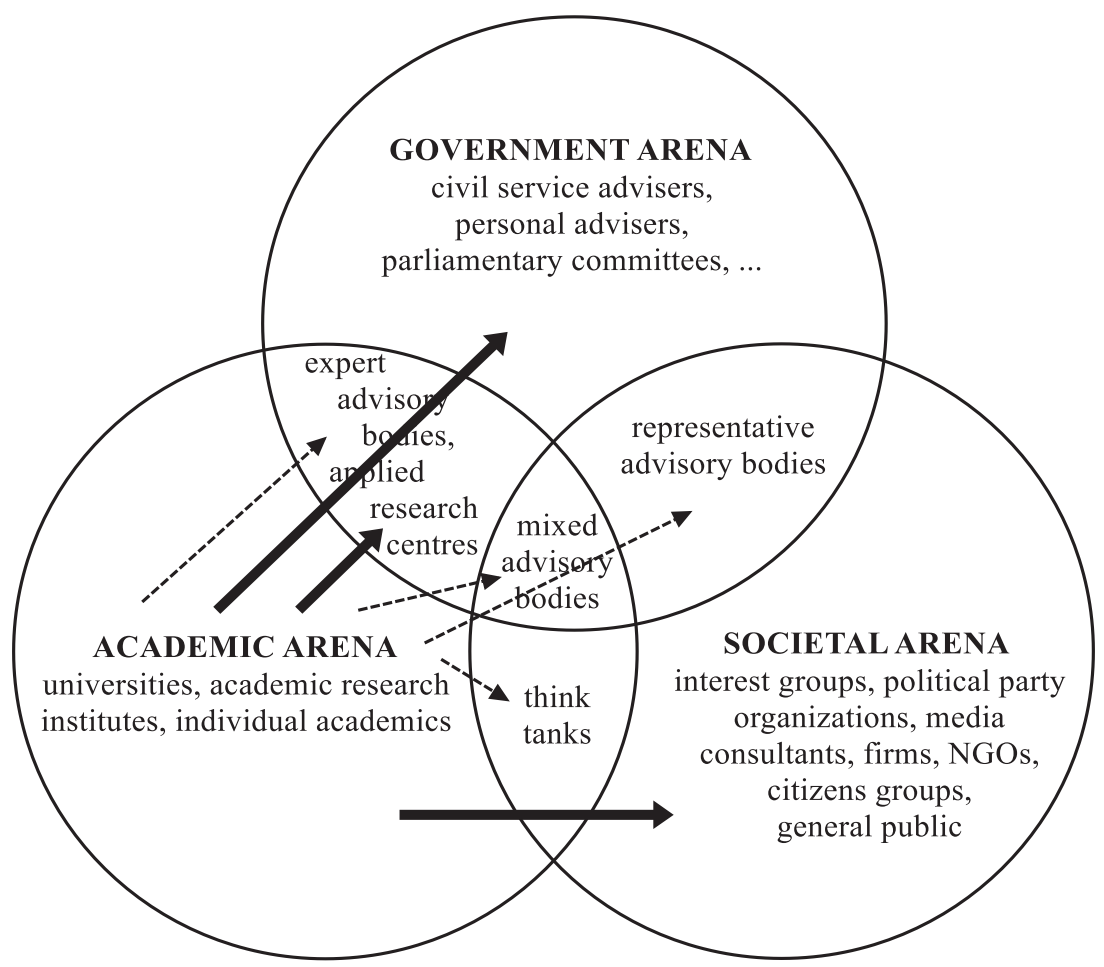

Fig. 5.1 Advisory arenas in the policy advisory system-Belgium. (Source: Adapted from Blum \& Brans, 2017) 
Table 5.1 Frequency and types of advice $\%(N)$ - Belgium

\begin{tabular}{lll}
\hline & $\begin{array}{l}\text { Belgium } \\
(N=87)\end{array}$ & $\begin{array}{l}\text { All } \\
\text { respondents } \\
(N=2354)\end{array}$ \\
\hline I provide data and facts about policies and political phenomena & $\begin{array}{l}63.2 \% \\
(55)\end{array}$ & $\begin{array}{l}45.7 \% \\
(1076)\end{array}$ \\
& $55.2 \%$ & $49.8 \%$ \\
I analyse and explain the causes and consequences of policy & $(48)$ & $(1172)$ \\
problems & $49.4 \%$ & $43.5 \%$ \\
I evaluate existing, policies, institutional arrangements, etc. & $(43)$ & $(1024)$ \\
& $54.0 \%$ & $31.3 \%$ \\
I offer consultancy services and advice, and make & $(47)$ & $(737)$ \\
recommendations on policy alternatives & $13.8 \%$ & $15.8 \%$ \\
I make forecasts and/or carry out polls & $(12)$ & $(372)$ \\
& $26.4 \%$ & $29.7 \%$ \\
I make value judgements and normative arguments & $(23)$ & $(699)$
\end{tabular}

\section{Source: ProSEPS survey data}

Notes: Question: "How often, on average, during the last three years, have you engaged in any of the following advisory activities with policy actors (policymakers, ministry officials, interest groups, political parties, etc.)?"; including only those respondents who indicated 'at least once per year' 'once per month' or 'once per week'

The differences in the frequency of policy advice activities are particularly marked as regards the provision of data and facts $(63 \%$ of Belgian political scientists compared to a European average of $45 \%$ ), and the provision of consultancy services and recommendations (54\% compared to 31\%) (Table 5.1).

Political scientists in Belgium are less frequently involved in forecasting and polling, which seems to be a niche reserved for a few scholars only. Similarly, about a quarter of the Belgian sample indicates making value judgements and normative arguments at least once a year. This is slightly lower than the European average of $30 \%$. It should be said that respondents may be reluctant to declare that they actually make value judgements and engage in normative advice giving.

\subsubsection{Distribution of Advisory Roles and the Demographics of Ideal Types}

The distribution of types of advisory role in Belgium differs from the overall distribution of types in the survey sample. To be precise, the share of experts and opinionating scholars is higher than average, which results 
Table 5.2 Advisory roles-Belgium

\begin{tabular}{lccc}
\hline Ideal type & $\begin{array}{c}\text { Total number in } \\
\text { Belgium }\end{array}$ & $\begin{array}{c}\text { Percentage in } \\
\text { Belgium }\end{array}$ & $\begin{array}{c}\text { Percentage in overall } \\
\text { sample }\end{array}$ \\
\hline Pure Academic & 5 & $5.8 \%$ & $20.3 \%$ \\
Expert & 32 & $36.8 \%$ & $26.6 \%$ \\
Opinionating & 49 & $56.3 \%$ & $48.7 \%$ \\
scholar & & $1.2 \%$ & $4.4 \%$ \\
Public Intellectual & 1 & & \\
\hline
\end{tabular}

Source: ProSEPS survey data

Notes: Advisory types operationalized on the basis of the content and frequency of advice. See Chap. 3

from the higher level of advisory activity engaged in within Belgium. Likewise, pure academics are much less common in Belgium than on average in Europe. The outspoken public intellectual is a rarity in Belgium, with only one political scientist from the sample falling into this category (Table 5.2).

The average age of the 87 respondents in Belgium is 43.6, which is slightly below the European average of 46.2. Furthermore, political science in Belgium (and Europe in general) is dominated by male scholars. Only $34.5 \%$ of the Belgian political science respondents were female.

Certain characteristics of policy advice, and the differences between advisory role types, are discussed in the following sections of this chapter. Two things ought to be pointed out first, however. The small size of the group ought to be taken into account when interpreting the figures for pure academics. This is because outliers can significantly affect the distribution of the data. Secondly, the sole public intellectual in the sample has been integrated into the group of opinionating scholars, in order to maintain anonymity throughout the remainder of the analysis.

The investigation of ideal types by age shows that pure academics (av. 50.6 years) tend to be considerably older than experts (av. 41.8 years) and opinionating scholars (av. 44 years). An age effect appears to come into play in regard to the roles taken up by political scientists: the older academics become, the more limited their advisory activities will be. Alternatively, the results may point to generational differences between political scientists, where a younger generation of academics prefers to be more publicly visible than the older generation (Table 5.3).

Looking at the ideal types by gender, we find that female political scientists are mostly experts (40.6\%). Pure academics account for only $20 \%$ 
Table 5.3 Ideal type by age-Belgium

\begin{tabular}{lccc}
\hline Age group & $\begin{array}{c}\text { Pure academic } \\
(N=5)\end{array}$ & $\begin{array}{c}\text { Expert } \\
(N=32)\end{array}$ & $\begin{array}{c}\text { Opinionating scholar } \\
(N=50)\end{array}$ \\
\hline 35 years or under & $20 \%$ & $18.8 \%$ & $28 \%$ \\
$35-50$ years & $0 \%$ & $65.6 \%$ & $44 \%$ \\
Over 50 years & $80 \%$ & $15.6 \%$ & $28 \%$ \\
\hline
\end{tabular}

Source: ProSEPS survey data

of the female respondents in the sample, while there are $32 \%$ female opinionating scholars. Female political scientists are also younger than men (40.9 years compared to 45.2 years on average). This may indicate that political science in Belgium is slowly moving towards greater gender equality.

\subsubsection{Channels of Advice Across Types of Role}

A variety of advisory channels are often employed by political scientists in Belgium. Respondents mainly provide their advice through publications and research reports. Opinionating scholars use such channels of advice more often than experts, who are more inclined to provide training and to write policy briefs. This corresponds to the conceptual model of role types. For experts, training is an important way of transferring knowledge and best practices.

While opinionating scholars use traditional and new media as typical avenues for the dissemination of advice, they also produce publications and research reports-indeed, more so than the experts. This may indicate that opinionators attach value to including evidence in their advice (Table 5.4).

Furthermore, all Belgian political scientists prefer certain particular modes of dissemination, namely face-to-face contact and workshops or conferences, to other modes. The phone and e-mails are relied upon much less frequently. As in the previous findings, opinionating scholars are generally more active advisors. They rely much more on all available modes of advice dissemination than the experts in the sample. To be precise, the four dissemination modes are used on average by $62 \%$ of opinionating scholars, compared to $44 \%$ of experts. 
Table 5.4 Channels of advice dissemination/Pathways to impact \% $(N)$-Belgium

\begin{tabular}{lcc}
\hline & $\begin{array}{c}\text { Expert } \\
(N=32)\end{array}$ & $\begin{array}{c}\text { Opinionating scholar } \\
(N=50)\end{array}$ \\
\hline Publications & $50 \%(16)$ & $78 \%(39)$ \\
Research reports & $56.3 \%(18)$ & $68 \%(34)$ \\
Policy reports, briefs and memos & $43.8 \%(14)$ & $42 \%(21)$ \\
Traditional media articles & $31.3 \%(10)$ & $44 \%(22)$ \\
Blog pieces and social media & $15.6 \%(5)$ & $30 \%(15)$ \\
Training courses & $46.9 \%(15)$ & $26 \%(13)$ \\
\hline
\end{tabular}

Source: ProSEPS survey data

Notes: Question: "Over the past three years, how frequently have you used any of the channels below to provide policy advice and/or consulting services?"; including only those respondents who indicated 'at least once per year' 'once per month' or 'once per week'

\subsection{Resisting Devolution? Policy Advice by Political Scientists Across the Language Divide}

The centripetal and bipolar nature of the Belgian Federation raises the question as to what extent Belgian political science has become federated, and whether the advisory activities of francophone and Dutch-speaking political scientists have become fragmented. In what follows, we first examine the advisory activities of the two political science communities based on the survey data. Secondly, we present a remarkable case of crossregional cooperation between political scientists, involving a Belgian academic cross-border think tank that advised societal and political actors to create a federal electoral district in order to counter the bipolar nature of political debate in the Belgian federation.

\subsubsection{Advisory Profile and Activities of Dutch-Speaking and French-Speaking Political Scientists}

The number of respondents is a representative linguistic sample of the total population of 328 political scientists in Belgium, which consists of 48\% Dutch-speaking, 50\% French-speaking and 2\% English-speaking academics. Half of the 87 respondents to the survey are from Dutch-speaking universities $(N=44), 46 \%$ from French-speaking universities $(N=40)$, and $3.5 \%$ of them work in English language institutions $(N=3)$ such as the Vesalius College in Brussels or the College of Europe in Bruges. 
What is the profile of Belgian political scientists across the two language communities in terms of their advisory activities? How similar or different are their substantive and sub-disciplinary foci?

First, the analysis shows that Dutch-speaking scholars are more active than their French-speaking colleagues. In fact, the latter group resembles more closely the average European respondent. French-speakers are more involved in polling, though-an effect of specialized investment in electoral studies (Table 5.5).

Second, there are some similarities between political scientists in French-speaking (FS) and Dutch-speaking (DS) universities, as regards their sub-disciplinary specializations. Some two-thirds of respondents consider themselves to be experts in core political science issues. However, there are also differences between the two main language groups. Public administration appears a more established sub-discipline within the Dutchspeaking political science community. Security studies, local government and political theory also display certain regional differences, the former two being stronger at Dutch-speaking universities, while political theory is stronger within the francophone academic community (Table 5.6).

Third, the substantive focus of political scientists' policy advice reflects their areas of expertise. The main topics of advice are general issues of government and public administration or electoral reform-and to a lesser extent international affairs, development aid and EU-related matters. The

Table 5.5 Frequency and types of advice by language group $\%(N)$ - Belgium

\begin{tabular}{lll}
\hline & $\begin{array}{l}D S \\
(N=44)\end{array}$ & $\begin{array}{l}F S \\
(N=40)\end{array}$ \\
\hline $\begin{array}{l}\text { I provide data and facts about policies and political phenomena } \\
\begin{array}{l}\text { I analyse and explain the causes and consequences of policy } \\
\text { problems }\end{array}\end{array}$ & $61 \%(27)$ & $\begin{array}{l}55 \%(22) \\
47.5 \%(19)\end{array}$ \\
$\begin{array}{l}\text { I evaluate existing, policies, institutional arrangements, etc. } \\
\begin{array}{l}\text { I offer consultancy services and advice, and make } \\
\text { recommendations on policy alternatives }\end{array}\end{array}$ & $57 \%(25)$ & $42.5 \%(17)$ \\
$\begin{array}{l}\text { I make forecasts and/or carry out polls } \\
\text { I make value judgements and normative arguments }\end{array}$ & $7 \%(3)$ & $22.5 \%(9)$ \\
\hline
\end{tabular}

Source: ProSEPS survey data

Notes: Question: "How often, on average, during the last three years, have you engaged in any of the following advisory activities with policy actors (policymakers, ministry officials, interest groups, political parties, etc.)?"; including only those respondents who indicated 'at least once per year' 'once per month' or 'once per week' 
Table 5.6 Sub-

disciplinary focus of political scientists at Dutch-speaking and French-speaking universities \%-Belgium

\begin{tabular}{lrl}
\hline & DS & \multicolumn{1}{c}{$F S$} \\
\hline Political science & $64 \%$ & $62.5 \%$ \\
Public policy & $29.5 \%$ & $35 \%$ \\
Public administration & $36 \%$ & $15 \%$ \\
Social policy and welfare & $7 \%$ & $22.5 \%$ \\
Environmental policy & $7 \%$ & $17.5 \%$ \\
Urban studies & $11 \%$ & $2.5 \%$ \\
Economics & $9 \%$ & $2.5 \%$ \\
Gender studies & $9 \%$ & $2.5 \%$ \\
\hline
\end{tabular}

Source: ProSEPS survey data

Notes: Question: "Which categories best describe your area of expertise? Please select the three main categories"; data only reported if $\mathrm{rf}>6 \%$

results reveal a greater concentration of advice topics among Dutchspeaking political scientists, than among francophone scholars whose attention to policy issues is more evenly distributed. The comparatively strong focus on migration issues among French-speaking political scientists is remarkable, given the higher level of politicization of this topic in the Dutch-speaking part of the country.

Certain issues appear less frequently on the advisory agenda of Belgian political scientists: issues such as energy, labour, foreign trade and technology. These matters may be more the territory of scholars in other disciplines, such as economists and engineers (Table 5.7).

\subsubsection{The Locus of Belgian Political Science Advice: Federal or Devolved?}

What is the primary locus of policy advisory activities, who are the recipients of advice, and which government levels are targeted by political scientists on both sides of the language divide?

The civil service and civil society organizations are the primary recipients of policy advice in Belgium. The civil service receives more advice from political scientists based at Flemish universities, while the latter category is provided with more advice from political scientists based at French-speaking universities. Think tanks are targeted to a much smaller degree by both groups of political scientists, and are relative newcomers to the Belgian advisory scene. Nor is there any great degree of reaching out 
Table 5.7 Substantive focus of policy advice $\%$-Belgium

\begin{tabular}{lcc}
\hline & $D S$ & $F S$ \\
\hline Government and Public administration, electoral reform & $52 \%$ & $40 \%$ \\
International affairs, development aid, EU & $30 \%$ & $30 \%$ \\
Immigration, integration, ethnic minorities & $14 \%$ & $25 \%$ \\
Civil rights, political rights, gender issues & $14 \%$ & $20 \%$ \\
Environment & $11 \%$ & $17.5 \%$ \\
Social welfare & $7 \%$ & $15 \%$ \\
Education & $9 \%$ & $7.5 \%$ \\
Energy & $4.5 \%$ & $10 \%$ \\
Labour & $4.5 \%$ & $10 \%$ \\
Crime, law and order & $7 \%$ & $5 \%$ \\
Public works, urban planning & $7 \%$ & $5 \%$ \\
Technology & $2 \%$ & $7.5 \%$ \\
Foreign Trade & $7 \%$ & $0 \%$
\end{tabular}

Source: ProSEPS survey data

Notes: Question: "With which substantive policy areas is your advice concerned?"; data only reported if rf $>6 \%$ for one of the two communities

to private interest groups or political parties, as is also the case in the rest of Europe (Table 5.8).

Furthermore, Flemish political scientists interact more with formal advisory bodies and with international organizations, while their colleagues in francophone Belgium focus more on providing advice to legislators.

Marked differences exist in the degree of formality of the advice provided. French-speaking political scientists resort more often to formal ways of advising (45\% FS vs. 15\% DS) whereas Dutch-speaking political scientists in Belgium more often alternate between formal and informal ways ( $54 \%$ DS vs. $26 \%$ FS). We have already established that Dutchspeaking political scientists' advisory activities are developed to a greater degree than those of their French-speaking counterparts, and this clearly comes with a mixed repertoire of formal and informal ways of connecting to recipient actors.

Political scientists across the country primarily target both the subnational and national level. It appears that the devolution of powers has increased the possible locations of policy advice, and has not led to a shift from one governmental level to another. In addition, the national level is considered slightly more important than the subnational level by 
Table 5.8 Recipients

of advisory activities

$\%$-Belgium

\begin{tabular}{lll}
\hline & \multicolumn{1}{c}{ DS } & \multicolumn{1}{c}{ FS } \\
\hline Civil service & $68 \%$ & $55 \%$ \\
Civil society groups & $45.5 \%$ & $62.5 \%$ \\
Executive politicians & $45.5 \%$ & $30 \%$ \\
International organizations & $43 \%$ & $25 \%$ \\
Advisory bodies & $43 \%$ & $22.5 \%$ \\
Legislative politicians & $32 \%$ & $42.5 \%$ \\
Think tanks & $25 \%$ & $27.5 \%$ \\
Political parties & $27 \%$ & $25 \%$ \\
Private interest groups & $23 \%$ & $17.5 \%$ \\
\hline
\end{tabular}

Source: ProSEPS survey data

Note: Question: "With which actors did you engage in knowledge exchange, advisory or consulting activities during the last three years?"

respondents in both language communities (64\% vs. 57\% for DS, $67.5 \%$ vs. $\mathbf{5 2 . 5 \%}$ for FS). Conversely, the international level of government is not the prime focus of the Belgian political science community (16\% DS; $12.5 \% \mathrm{FS})$. The provision of advice to EU actors, in turn, is more of a concern $(25 \%$ DS; $27.5 \%$ FS $)$ than it is at the aggregate level of the countries in the sample $(12.9 \%)$. This is not surprising given the proximity of the various $\mathrm{EU}$ institutions.

These findings underscore the saliency of the remaining federal powers to the advisory activities of Belgian political scientists, despite the substantial devolution of powers within the country. There are no long-term data on advisory activities across government levels however, and for this reason, we cannot draw any conclusions regarding changes over time in the importance of governance levels and regarding effects of the federalisation process in Belgium on the advisory activities of its political science community.

\subsubsection{Diverging Opinions on the Relevance of Advisory Activities}

The survey included several normative statements about the policy advisory activities of political scientists. While a majority of Belgian academics consider it a professional obligation to engage in public debate, a smaller number of academics agree that political scientists should be involved in policy-making. In addition, a large group of respondents thinks that 
Table 5.9 Normative views on policy advice $\%$-Belgium

\begin{tabular}{lll}
\hline & \multicolumn{1}{c}{$D S$} & \multicolumn{1}{c}{$F S$} \\
\hline $\begin{array}{l}\text { Political scientists should become involved in policy-making. } \\
\text { Political scientists have a professional obligation to engage in public } \\
\text { debate. }\end{array}$ & $48 \%$ & $45 \%$ \\
$\begin{array}{l}\text { Political scientists should provide evidence-based knowledge and } \\
\text { expertise outside academia, but not be directly involved in } \\
\text { policy-making }\end{array}$ & $70 \%$ & $82.5 \%$ \\
$\begin{array}{l}\text { Political scientists should refrain from direct engagement with policy } \\
\text { actors }\end{array}$ & $9 \%$ & $22.5 \%$ \\
\hline
\end{tabular}

Source: ProSEPS survey data

Notes: Question: “To what extent do you agree with the following statements?"; including only those respondents who indicated 'fully agree' or 'somewhat agree'

evidence is key. These findings are consistent across the language divide (Table 5.9).

There are, however, some notable differences between academics in the two language communities. French-speaking political scientists are more distant and cautious in the degree to which they feel it is important to take up advisory activities. Nearly a quarter of them think political scientists should refrain from any direct engagement. Conversely, Flemish political scientists are more inclined to bring evidence to the public debate (Table 5.9).

The vast majority of political scientists in Belgium are intrinsically motivated to contribute to society through providing advisory and consultancy services. Other forms of motivation include staying active minded and considering advice as the professional duty of scholars. While policy advice may also be instrumental to the pursuit of an academic career, this motivation appears much more important to Dutch-speaking scholars than to French-speakers. Also, the perception of the university's recognition of advisory work for the purposes of one's career development is more evident among Dutch-speaking scholars (Table 5.10).

\subsubsection{The Pavia Group Advice to Install a Federal Electoral District}

The idea came up of doing something collective, of some magnitude and duration, in favour of a proposal which we thought was important enough to deserve a broad public discussion: the proposal of a federale kieskring or circonsciption fédérale, that is the creation, next to the provincial electoral districts, of a 
Table 5.10 Intrinsic and extrinsic motives for policy advisory and consulting activities \%-Belgium

\begin{tabular}{|c|c|c|}
\hline & $D S$ & FS \\
\hline I like to stay active minded & $57 \%$ & $47.5 \%$ \\
\hline It helps advance my academic career & $32 \%$ & $15 \%$ \\
\hline $\begin{array}{l}\text { It helps expand my career options and provides alternative sources of } \\
\text { finance }\end{array}$ & $52 \%$ & $35 \%$ \\
\hline $\begin{array}{l}\text { Engagement in advisory or consulting activities is part of my } \\
\text { professional duty as a political scientist }\end{array}$ & $79.5 \%$ & $67.5 \%$ \\
\hline I like to make a contribution to society & $91 \%$ & $85 \%$ \\
\hline
\end{tabular}

Source: ProSEPS survey data

Notes: Question: "How important are the following reasons for your engagement in advisory or consulting activities?"; the results only include those respondents who indicated 'fully agree' or 'somewhat agree'

country-wide electoral district in which a fraction of the members of Belgium's federal Chamber would be elected. (Van Parijs, 2019)

In the 1970s, the three traditional Belgian political parties (Christian Democratic, Socio-Democratic, and Liberal) each split into a Dutchspeaking party and a French-speaking party, and more recently two Green parties have been established. The ethno-linguistic party system in Belgium has also witnessed the rise of two nationalist parties in Flanders: the liberal conservative party 'New Flemish Alliance' (N-VA) and the extreme rightwing party 'Vlaams Belang' (formerly Vlaams Blok). The francophone party system has no nationalist equivalents, although some parties with regionalist tendencies do exist. The devolved party system, combined with provincial electoral lists, has contributed to the strongly bipolar nature of the Belgian state, and has rendered the achievement of compromises arduous. The lengthy government formation processes, with frequent deadlocks, demonstrate that parties often make promises at the expense of other areas of the country, and that federal consensus institutions have become weak.

The idea of creating a country-wide or 'federal' constituency alongside 11 provincial constituencies was conceived in order to alleviate the problem of delay and deadlock. Even if only $10 \%$ of the seats were allocated to this federal constituency, it would be expected to smoothen the dynamics of Belgium's federal politics. If well designed, the leaders of all parties would be willing to run for elections in this constituency and thereby 
become accountable to the whole of the country, instead of to their own province or community (Deschouwer \& Van Parijs, 2007, 2008, 2009).

The idea of creating a federal electoral district was conceived, substantiated and advocated by 'the Pavia Group"', a cross-linguistic academic think tank with 21 members $^{5}$ (La Libre, 2005), the majority of whom were political scientists whose sub-disciplinary specializations were primarily embedded in comparative politics and electoral behaviour. The group aimed for the widest possible academic representation in its membership, comprising academics at eight universities of different denominations and languages. A majority of these members were well-known contributors to public debate in the press, and on radio and television news programmes, and also frequent guests on election shows.

The first channel of advice chosen by the Pavia Group was the simultaneous publication of an opinion piece in both a Flemish and a Francophone quality newspaper in 2005 . After meetings with other experts and leading politicians, the Group's final proposal was presented to the press at the Belgian University Foundation in 2007, followed shortly afterwards by interviews in the television current affairs programme Terzake (2007), and by a debate with a prominent political opponent from the Flemish nationalist party N-VA published in Knack Magazine (2007). The detailed proposal was published in La Revue Nouvelle and Samenleving en Politiek, and was also comprehensively discussed in a Cahier of the Centre de Recherche et d'Information socio-politiques (Sinardet, 2012). Many more opinion pieces followed, as did the publication of an e-book in English which eventually made it to a bicameral parliamentary discussion in 2014 .

The Pavia Group explored all possible channels of advice. In addition to their publications, they also advocated their proposal through workshops, and through meetings with secretaries of state responsible for

\footnotetext{
${ }^{4}$ The Pavia group was named after the street name of the house in Bruxelles where the group first met.

${ }^{5}$ Initial members were the scholars who signed the said opinion piece Een kieskring voor alle Belgen/La démocratie belge enrayée (De Standaard et La Libre, 4 février 2005), namely: Kris Deschouwer (VUB \& Lausanne), Philippe Van Parijs (UCL \& Harvard), Rik Coolsaet (UGent), Pascal Delwit (ULB), Lieven De Winter (UCL \& KUB), Marco Martiniello (ULg), Koen Raes (UGent), Benoit Rihoux (UCL), Toon Vandevelde (KU Leuven), Pierre Verjans (ULg) and Stefaan Walgrave (UA). They were later joined by Carl Devos (UGent), Marc Hooghe (KU Leuven), Petra Meier (UA), Olivier Paye (USaint-Louis), Jean-Benoit Pilet (ULB), Gérard Roland (UCBerkeley \& ULB), Dave Sinardet (UA \& USaint-Louis), Yannick Vanderborght (USaint-Louis \& UCLouvain) et Caroline Van Wynsberghe (UCLouvain).
} 
institutional reform, and even with the Prime Minister. With institutional reform shelved under the Michel-government (2014-2018), the debate surrounding the proposal was stymied. However, the idea survived, and one political party continued to explicitly promote the proposal. The proposal was subsequently picked up by the new Re-Bel think tank on Belgian Federal Institutions in 2020, with a discussion on how a federal district might prevent federal blockages.

This case of 15 years of discussion of institutional reform in Belgium exhibits certain key features of the Belgian political advisory system, with a strong emphasis on consensus-based advice and the representation of the different linguistic and denominational affiliations of the experts involved. It also shows that political scientists with advisory roles have to deal constantly with the political sensitivity of the subject matter. Furthermore, the case illustrates the survey's findings. It portrays the (mostly male) community of Belgian political scientists as active advisors, trying to change society through a plethora of media channels and other modes of dissemination, and engaging with multiple recipients of their advice. At the same time, the case is an example of how leading political scientists in Dutchspeaking and francophone Belgium are not locked in separate regional policy advisory bubbles. Moreover, the case is not unique, as the crosslinguistic involvement of political scientists in the G-1000, a democratic innovation initiative and platform, testifies (www.G1000.org).

\subsection{Conclusion}

In Belgium, political scientists as experts or opinionating scholars are very much committed to policy advisory activities. Scholars at universities in the Dutch-speaking part of the country are more active advisors as compared to their colleagues in other European countries. The small size of this densely-populated country, which facilitates interpersonal ties, may be conducive to such activities. Another explanation for this relatively high level of engagement in advisory work, may be the resources supplementing the relatively limited in-house advisory capacity of governments. Belgian governments' science policies, albeit with certain variations between different levels of government, invested in applied social science programmes at least until the mid-2010s, as a result of which scientific expertise and knowledge on policy issues was actively sought. In the absence of further research findings, we may also speculate that Belgium's pillarized society has produced communities that value volunteer work 
and disinterested dedication to the group's interests. By extension, this will engender a relatively strong commitment on the part of academics towards 'service to the community' - what is called 'the third mission of universities'. Political scientists are also thought to offset the limited numbers and resources of political journalists operating in media organizations, with the latter actively seeking to engage political scientists for fact finding and expert interviews.

Belgian political scientists are thus active players in the Belgian policy advisory system, and the survey results offer an interesting view of this system. While the civil service remains the main recipient of such advice, its provision to civil society is quite important as well, and probably on the increase. However, as the survey is synchronic, it is hard to tell whether or not the policy advisory system is moving towards greater pluralization and externalization. What is evident is that the traditional organizations linking government to society, that is, the advisory bodies are not the first of the political scientists' targets. In these bodies, lay and representative interest-based expertise prevails. The advisory activities of political scientists, on the other hand, mainly concern the government arena, and take the form of direct advice to the nation's civil service, and to a lesser extent target executive and legislative politicians. While advice is also offered to the public arena, and in particular to civil society, little advice is provided to Belgium's private interest groups. Political scientists also maintain their distance from consultancy firms, which in recent years have considerably expanded their public sector activities. Think tanks have also become more active in Belgium, but from the viewpoint of political scientists' advisory activities they remain rather isolated actors in the policy advisory system.

What about the typical political-systemic features of the Belgian policy advisory system, such as consociationalism, partitocracy, and federalism? Well, the tradition of neo-corporatist consociationalism survives in the nature and recipients of advisory activities, as well as in the attention paid to ensure balanced representation of different denominational institutions in research consortia. Neither the survey nor the case in question has helped us to evaluate the partitocratic impact on policy advisory activities, beyond certain speculation about the predominance of partitocratic gatekeepers of policy advice. What about the federalisation of the policy advisory system? The survey has not provided any strong evidence of devolved policy advisory systems, at least not as far as it concerns the governmental level advice is targeted at. Actors at the federal level are no less important targets than are those at the subnational level. Moreover, the proposal to 
create a federal electoral district meets, both in substance and in the composition of the political scientists who devised it, the expectation that political scientists have not retreated into regional policy advisory systems.

What then can explain the fact that Dutch-speaking political scientists are more active advisors than their colleagues at French-speaking universities are? The survey results suggest that the importance that Dutchspeaking political scientists in particular give to their advisory roles, is related to professional norms and incentives. They perceive advisory activities as being instrumental to the advancement of their careers, more than their French-speaking colleagues do. The extent to which being a public person increases one's academic reputation, and increases the likelihood of being appointed to honorary positions (e.g. in the academy), and of receiving additional research funds (through ministerial mandates), has yet to be investigated. Whether roles as experts and opinionating scholars generate prestige and are encouraged and rewarded by universities, clearly merits further study.

Two further reasons for the aforesaid discrepancy may be the relatively greater importance of public administration studies at Flemish universities, and the relatively stronger administrative reform agenda of the Flemish government, backed by several generations of applied research. The differences in the degree to which Belgian political scientists actively provide advice may thus have been impacted by diverging policy agendas. A comparatively stronger administrative reform agenda in Flanders may have boosted advisory activities, particularly in the public administration community. Stronger mandates for economic and social recovery in francophone Belgium are consistent with the relatively greater attention paid to advising on issues of welfare and social policy, as well as with the shift in advisory activities away from political scientists towards economists. Nonetheless, empirical research beyond what is currently speculated is required in order to test such hypotheses. Matching the results of this chapter's analysis of the supply side with a demand-side perspective on the similarities and differences in comparative agendas, governmental policy advisory styles, and policy sectors, is a worthy idea for future research.

\section{REFERENCES}

Aubin, D., Brans, M., \& Fobé, E. (2017). The policy analytical profession in Belgium. In M. Brans \& D. Aubin (Eds.), Policy analysis in Belgium (pp. 13-34). Policy Press. 
Blum, S., \& Brans, M. (2017). Academic policy analysis and research utilization for policymaking. In Brans, M., Geva-May, I. \& M. Howlett (Eds.), Handbook of Comparative Policy Analysis (pp. 341-359). Routledge.

Brans, M., Aubin, D., De Visscher, C., Fobé, E., Meert, A., \& Squevin, P. (2022 forthcoming). The end of the party politicisation of public administration: A fata morgana? In P. Baudewyns, M. Brans, M. Reuchamps, B. Rihoux, \& V. Van Ingelgom (Eds.), Partitocracy in Belgium. The winter on democracy. Presses Universitaires de l'Université Catholique de Louvain.

Brans, M., \& Blum, S. (2020). From 'speaking truth to power' to 'evidence free(d) policymaking? The new faces of the science-policy nexus. Unpublished paper, KU Leuven Public Governance Institute.

Brans, M., De Visscher, C., Gouglas, A., \& Jaspers, S. (2017a). Political control and bureaucratic expertise: Policy analysis by ministerial cabinet members. In M. Brans \& D. Aubin (Eds.), Policy analysis in Belgium (pp. 57-77). Policy Press.

Brans, M., Aubin, D., \& Smet, V. (2017b). Policy analysis by academics. In M. Brans \& D. Aubin (Eds.), Policy analysis in Belgium (pp. 275-293). Policy Press.

De Standaard. (2005, februari 4). Een kieskring voor alle Belgen, Collectief opiniestuk.

De Standaard. (2017, October 14). Demir haalt uit naar wetenschappers achter kritisch armoederapport. https://www.standaard.be/cnt/ dmf20171014_03132103.

De Standaard. (2019). Niet zo links als rechts beweert. 21.09.2019.

De Winter, L., \& Dumont, P. (2006). Do Belgian parties undermine the democratic chain of delegation? West European Politics, 29(5), 957-976.

De Winter, L., Frognier, A.-P., Dezeure, K., Berck, A.-S., \& Brans, M. (2007). Belgium: From one to two political sciences? In H. D. Klingemann (Ed.), The state of political science in Western Europe (pp. 57-71). Opladen \& Farmington Hills.

Deschouwer, K., \& Van Parijs, P. (2007, April). Une circonscription fédérale pour tous les Belges. La Revue nouvelle, 4, 12-23.

Deschouwer, K., \& Van Parijs, P. (2008, March). Een federale kieskring voor een gezonde federatie. Samenleving en Politiek, 15(3), 43-52.

Deschouwer, K., \& Van Parijs, P. (2009, July). Electoral engineering for a stalled federation. Re-Bel e-book $\mathrm{n}^{\circ} 4$.

Fobé, E. (2020). The policy analytical capacity of in-house policy workers in Belgium. PhD thesis, Faculty of Social Sciences, Leuven.

Fobé, E., Brans, M., Vancoppenolle, D., \& Van Damme, J. (2013). Institutionalized advisory systems: An analysis of member satisfaction of advice production and use across nine strategic advisory councils in Flanders (Belgium). Policy of Society, 32(3), 225-240. 
Fobé, E., Biard, B., Schiffino, N., \& Brans, M. (2017). Policy advisory bodies in Belgium. In M. Brans \& D. Aubin (Eds.), Policy analysis in Belgium (pp. 151-170). Policy Press.

Fraussen, B., \& Beyers, J. (2016). Who's in and who's out? Explaining access to policymakers in Belgium. Acta Politica, 51(2), 214-236.

Ilonszki, G., \& Roux, C. (Eds.). (2021). Opportunities and challenges for new and peripheral political science communities. A consolidated discipline? Palgrave Macmillan.

Knack. (2007, februari 14). Walgrave, Stefaan and De Wever, Bart. Een federale kieskring? Ja/Nee.

La Libre Belgique. (2005, February 4). La démocratie belge enrayée, Carte blanche collective.

Lijphart, A. (2012). Patterns of democracy. Government forms and performance in thirty-six countries ( 2 nd ed.). Yale University Press.

Mabille, X. (1997). Histoire politique de la Belgique. Facteurs et acteurs de changement. CRISP.

Pattyn, V., Van Hecke, S., Pirlot, P., Rihoux, B., \& Brans, M. (2017). Ideas as close as possible to power: Belgian political parties and their study centres. In M. Brans \& D. Aubin (Eds.), Policy analysis in Belgium (pp. 173-191). Policy Press.

Pattyn, V., Blum, S., Fobé, E., Pekar-Milicevic, M., \& Brans, M. (2019). Academic policy advice in consensus-seeking countries: The cases of Belgium and Germany. International Review of Administrative Sciences. https://doi. org/10.1177/0020852319878780

Raymaekers, P., \& Brans, M. (2020). Nudging in perspectief. De verbreding van gedragsinzichten in beleid. Beleidsonderzoek Online, June 2020, 1-28.

Sinardet, D. (2012). Le projet de circonscription fédérale. Courrier hebdomadaire du CRISP n ${ }^{\circ} 2142$.

Straßheim, H., \& Kettunen, P. (2014). When does evidence-based policy turn into policy-based evidence? Configurations, contexts and mechanisms. Evidence \& Policy, 10(2), 259-277.

Swenden, W., Brans, M., \& De Winter, L. (2006). The politics of Belgium: Institutions and policy under bipolar and centrifugal federalism. West European Politics, 29(5), 863-873.

Terzake. (2007, februari 14). Kris Deschouwer in gesprek met Siegfried Bracke. Brussel, VRT.

van de Werfhorst, H. (2020). Are universities left-wing bastions? The political orientation of professors, professionals, and managers in Europe. The British Journal of Sociology, 71(1), 47-73.

Van Gasse, B. (2018). Beleidsadvisering in het federale Parlement. Een analyse van de uitgenodigde experts in de parlementaire hoorzittingen van de vaste commissies 
van de Kamer van Volksvertegenwoordigers in de periode 2011-2014. Master dissertation, KU Leuven, Faculty of Social Sciences.

Van Parijs, P. (2019, February 8). Il Pavese. In Emeritus celebration Kris Deschouwer (pp. 35-42). University Foundation.

Van Damme, J., Brans, M., \& Fobé, E. (2011). Balancing expertise, societal input and political control in the production of policy advice. A comparative study of education councils in Europe. Halduskultuur-Administrative Culture, 12 (2), 126-145.

Vandeleene, A., De Winter, L., \& Baudewyns, P. (Eds.). (2019). Candidates, parties and voters in the Belgian partitocracy. Palgrave Macmillan. www.G1000.org

Open Access This chapter is licensed under the terms of the Creative Commons Attribution 4.0 International License (http://creativecommons.org/licenses/ by $/ 4.0 /$ ), which permits use, sharing, adaptation, distribution and reproduction in any medium or format, as long as you give appropriate credit to the original author(s) and the source, provide a link to the Creative Commons licence and indicate if changes were made.

The images or other third party material in this chapter are included in the chapter's Creative Commons licence, unless indicated otherwise in a credit line to the material. If material is not included in the chapter's Creative Commons licence and your intended use is not permitted by statutory regulation or exceeds the permitted use, you will need to obtain permission directly from the copyright holder.

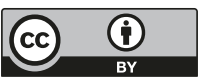

